\title{
Aktivitas Hidrolisis Ekstrak Kasar Lipase dari Kecambah Biji Kesambi (Schleichera oleosa L) dengan Variasi Waktu Perkecambahan
}

\author{
Gersandi Hendrik ${ }^{1}$, Mellissa Erlyn Stephanie Ledo ${ }^{1 *}$, dan Merpiseldin Nitsae ${ }^{1}$ \\ ${ }^{1}$ Fakultas Keguruan dan Ilmu Pendidikan, Universitas Kristen Artha Wacana, Kupang, Indonesia
}

\begin{abstract}
Kesambi seeds contained various fatty acid such as miristic acid, palmitic acid, stearic acid, aracidic acid, oleic acid and linoleic acid. Germination is a first stage for seeds plants development that supported by enzymes. Lipase enzyme have important roles for lipid degradation and sinthesys. The aim of this study to obtained hydrolysis activity and protein content of crude extract lipase from germinated kesambi seeds. The result of this study showed that the highest hydrolysis activity was founded in 13 days seeds germination 41,3 $\mathrm{U} / \mathrm{ml}$ hydrolysis activity, the highest protein content in 13 days seeds germination 1,11 gr/mL. the highest specific activity was found in 11 days seeds germination 69,20 U/gr, so the germinated kesambi seeds in 11 days recommended as lipase source.
\end{abstract}

Keywords : Schleichera oleosa L, germination, enzymes, lipase, hydrolysis.

\begin{abstract}
Abstrak
Biji kesambi mengandung beberapa jenis asam lemak seperti asam miristat, asam palmitat, asam stearat, asam arakidat, asam oleat dan asam linoleat. Proses perkecambahan merupakan tahap awal perkembangan tumbuhan berbiji yang didukung oleh peran enzim. Enzim lipase berperan untuk mengatur kecepatan pemecahan lemak dan sintesis lemak. Tujuan penelitian ini adalah untuk mengetahui aktivitas hidrolisis ekstrak kasar lipase kecambah biji kesambi dan kadar protein dalam ekstrak kasar lipase kecambah biji kesambi. Hasil penelitian ini menunjukan aktivitas hidrolisis ekstrak kasar lipase kecambah biji kesambi tertinggi adalah hari ke 13 sebesar 41,3 U/ml, kadar protein tertinggi pada hari ke 13 sebesar $1,11 \mathrm{gr} / \mathrm{mL}$, aktivitas spesifik tertinggi pada hari ke 11 sebesar 69,20 U/gr, sehingga penggunaan kecambah biji kesambi pada usia kecambah 11 hari direkomendasikan sebagai sumber lipase.
\end{abstract}

Kata kunci: Schleichera oleosa L, perkecambahan, ekstrak kasar lipase, hidrolisis, protein

\footnotetext{
*Corresponding author:

Mellissa Erlyn Stephanie Ledo

Program studi Pendidikan Biologi, Fakultas Keguruan dan Ilmu Pendidikan, Universitas Kristen Artha Wacana,

Jl. Adi Sucipto No. 147, Oesapa, Kupang, Indonesia, 85361

E-mail: mellissaerlynsledo@gmail.com
} 


\section{Pendahuluan}

Pohon kesambi (Schleichera oleosa

L) merupakan tumbuhan lokal di Nusa Tenggara Timur. Pohon kesambi (Schleichera oleosa L) dalam bahasa Timor dikenal dengan "usapi" dan dalam bahasa Rote yaitu "kule", masyarakat di Nusa Tenggara Timur memanfaatkan kayu kesambi sebagai jangkar kapal dan kayu bakar, buah sebagai makanan atau manisan. Selain kayu dan buah, bijinya kesambi juga memiliki manfaat yang sangat penting. Biji kesambi dapat dimanfaatkan sebagai pengganti minyak tanah yang digunakan pada pelita, karena mengandung asam lemak seperti asam miristat, asam palmitat, asam stearat, asam arakidat, asam oleat dan asam linoleat. Kandungan asam oleat memiliki persentase tertinggi yaitu berkisar 40-60\% (Seran, 2011).

Salah satu bagian tanaman yang berperan sebagai biokatalis adalah biji kesambi. Biji merupakan tempat cadangan makanan bagi calon tanaman. Cadangan makanan selama proses perkecambahan menjadi energi yang dibutuhkan untuk proses pertumbuhan. Perkecambahan merupakan tahap awal perkembangan suatu tumbuhan, khususnya tumbuhan berbiji. Dalam tahap ini, embrio didalam biji yang semula berada pada kondisi dorman mengalami sejumlah perubahan fisiologis yang menyebabkan biji berkembang menjadi tumbuhan muda (Sutopo, 2002).

Salah satu faktor yang mempengaruhi proses perkecambahan adalah enzim. Enzim merupakan protein yang dapat meningkatkan laju reaksi tanpa ikut bereaksi didalamnya. Enzim disebut juga sebagai biokatalisator, semua reaksi metabolisme dikatalis oleh enzim. Dalam reaksi metabolisme, enzim bekerja secara spesifik terhadap substrat (Sya'bani et al. 2017). Hasil dari reaksi hidrolisis lemak yaitu asam lemak dan gliserol. Enzim Lipase mengatur kecepatan pemecahan lemak dan sintesis lemak pada tahap perkecambahan dan pertumbuhan embrio. Secara umum biji-bijian yang mengandung lemak tinggi merupakan sumber lipase (Lotti dan Alberghina, 2007).

Hasil dari reaksi hidrolisis berupa asam lemak dapat dimanfaatkan dalam berbagai bidang misalnya pada bidang kosmetik, yaitu sebagai pengental, pelembab, dan pelembut. Pada industri makanan bayi, yaitu meningkatkan kecerdasan, menambah daya tahan dan stamina tubuh, mencegah dan mengatasi masalah gizi, seperti kurang vitamin, mengoptimalkan kecerdasan anak, sebagai antimikrobial pada indutri farmasi (melindungi tubuh dari virus herpes, HIV, dan bakteri Clamidya).

Penelitian ini bertujuan untuk menentukan aktivitas hidrolisis ekstrak kasar lipase dari kecambah biji kesambi (Schleichera oleosa $\mathrm{L}$ ) dengan waktu perkecambahan yang berbeda.

\section{Bahan Dan Metode}

Alat yang digunakan dalam penelitian ini adalah shaker; timbangan; gelas ukur $100 \mathrm{ml}$; sentrifuge; erlenmeyer; pipet tetes; pipet volume; kertas saring; corong pisah; buret dan statip; mortal dan alu; kertas $\mathrm{pH}$, spektrofotometer. Bahan yang digunakan dalam penelitian ini adalah biji kesambi, $\mathrm{Na}_{2} \mathrm{HPO}_{4}, \mathrm{NaH}_{2} \mathrm{PO}_{4}$, Buffer fosfat 0,1 M, pH 8,0, akuades, $\mathrm{NaOH}$, indikator phenolptalein, minyak kelapa, $\mathrm{Na}_{2} \mathrm{CO}_{3}, \mathrm{CuSO}_{4} \cdot 5 \mathrm{H}_{2} \mathrm{O}, \mathrm{Na} \mathrm{K}$ -Tartarat, reagen Folin Ciocalteu

\section{Perkecambahan Biji Kesambi}

Perkecambahan biji kesambi dilakukan pada media pasir dengan perlakuan pendahuluan perendaman air sumur selama 24 jam kemudian ditanam pada bedeng pasir dengan ukuran bedeng 1 meter kemudian dilakukan penyiraman dengan air setiap hari. Hitungan awal perkecambahan dilakukan pada hari ke 5, 7, 9, 11, 13 dan digunakan sebagai sampel, dan diuji aktivitas hidrolisis lipase (Suita, 2012).

\section{Ekstraksi Lipase dari Kecambah Biji Kesambi}

Ekstraksi lipase dari biji kesambi menggunakan metode Sya'bani et al. (2017) yang telah dimodifikasi. Kecambah biji kesambi yang telah dibersihkan ditimbang sebanyak $5 \mathrm{~g}$ dan dihaluskan menggunakan mortal dan alu, lalu ditambahkan $25 \mathrm{ml}$ buffer fosfat 0,1 M pH 8,0 dan dihomogenkan. Kemudian didiamkan selama \pm 30 menit. Disaring menggunakan kertas saring, 
residunya kemudian dibuang, selanjutnya filtrat disentrifugasi pada kecepatan 12000 rpm selama 30 menit pada suhu $4^{\circ} \mathrm{C}$. Supernatan yang dihasilkan merupakan ekstrak kasar lipase kecambah biji kesambi.

\section{Uji Aktivitas Ekstrak Kasar Lipase Kecambah Biji Kesambi}

Reaksi hidrolisis dilakukan dengan cara mencampurkan $5 \mathrm{ml}$ substrat ( minyak kelapa) dengan enzim $5 \mathrm{ml}$, dishaker selama 30 menit dengan kecepatan $150 \mathrm{rpm}$ dan diinkubasi selama 30 menit, lalu ditambahkan indikator phenolptalien sebanyak 5 tetes, kemudian dititrasi dengan $\mathrm{NaOH} \mathrm{0,05} \mathrm{M}$ sampai terjadi perubahan warna menjadi merah muda, dengan ulangan sebanyak 3 kali. Aktivitas ekstrak kasar lipase kecambah biji kesambi dihitung dengan rumus :

(V NaOH sampel - $\mathrm{V} \mathrm{NaOH}$ kontrol) $\times 100 \mathrm{U} / \mathrm{ml}$ volume enzim

Uji aktivitas spesifik ekstrak kasar lipase kecambah biji kesambi:

$$
\text { AS }(\mathrm{U} / \mathrm{mg})=\frac{\text { Aktivitas enzim }}{\text { Total protein }}
$$

Keterangan :

$$
\begin{array}{ll}
\text { As } & \text { aktivitas spesifik enzim } \\
& \text { dalam mg protein }(\mathrm{U} / \mathrm{mg}) \\
\mathrm{AE} & =
\end{array}
$$

Total protein $=\mathrm{mg}$ protein $(\mathrm{mg} / \mathrm{ml})$

Setiap $1 \mathrm{ml} \mathrm{NaOH}$ 0,05 M setara dengan 100 unit aktivitas lipase.

\section{Penentuan Kandungan Protein Ekstrak} Kasar Lipase Kecambah Biji Kesambi

Pengukuran kandungan protein ekstrak kasar lipase kecambah biji kesambi dilakukan dengan metode Lowry. Ekstrak kasar lipase kecambah biji kesambi sebanyak $1 \mathrm{ml}$ ditambahkan $1 \mathrm{ml}$ reagen Lowry D, selanjutnya campuran divortex dan diinkubasi pada suhu kamar selama 10 menit. Campuran ditambah reagen Lowry E, kemudian diinkubasi selama 30 menit pada suhu kamar dengan sesekali divortex. Larutan diukur absorbansinya pada gelombang optimum BSA (Bovine Serum Albumin) yaitu pada panjang gelombang $542 \mathrm{~nm}$, kemudian kadar protein ditentukan dengan persamaan regresi linear kurva standar BSA.

\section{Hasil dan Pembahasan}

Perkecambahan adalah tahapan awal perkembangan suatu tumbuhan, khususnya tumbuhan berbiji. Dalam tahap ini embrio di dalam biji yang semula berada dalam kondisi dorman mengalami sejumlah perubahan fisiologis yang menyebabkan tumbuhan tersebut berkembang menjadi tumbuhan muda. Selama proses perkecambahan, biji akan melewati beberapa tahapan yaitu imbibisi (tahap penyerapan air), pembentukan enzim, pemanjangan sel radikula yang diikuti dengan munculnya radikula dari kulit biji, kemudian pertumbuhan kecambah.

Tipe perkecambahan benih berdasarkan letak daun tembaga atau kotiledon, tipe perkecambahan kesambi adalah epigeal (perkecambahan di atas tanah) dimana kotiledon berfungsi melakukan proses fotosintesis untuk menyuplai makanan selama daun belum terbentuk. Akar kecambah akan terus mengalami pertumbuhan selama perkecambahan sebagai gambaran terjadi perubahan panjang akar dapat dilihat pada Gambar 4.1. (Debaujon et al., 2007), mengatakan bahwa makromolekul yang dirombak selama perkecambahan selain dijadikan energi juga dibutuhkan dalam pembentukan sel-sel baru.
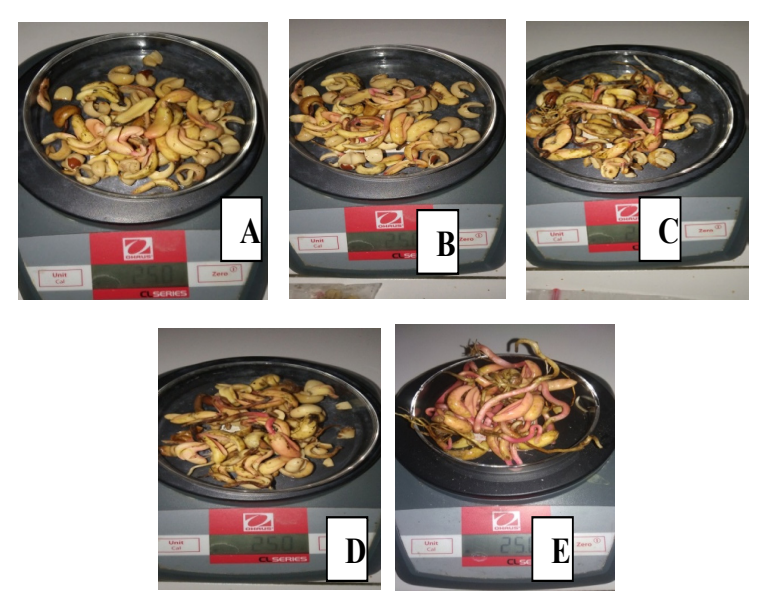

Gambar 1. (A) Kecambah biji kesambi hari ke-5, (B) Kecambah biji kesambi hari ke-7, (C) Kecambah biji kesambi hari ke- 9, (D) Kecambah biji kesambi hari ke-11, (E) Kecambah biji kesambi hari ke-13. 
Kecambah yang digunakan sebagai sampel pada penelitian ini yaitu kecambah yang berumur 5, 7, 9, 11, 13 hari seperti pada gambar 4.1 (a-e), karena pada proses perkecambahan biji, terdapat makromolekul yang harus di hidrolisis oleh enzim untuk menjadi molekul yang sederhana untuk digunakan selama biji berkecambah. Hal ini didukung oleh penelitian yang dilakuan oleh Permana et al. (2013), pada biji kakao pada hari ke 1 sampai hari ke 10. Selama terjadinya peristiwa perkecambahan, jaringan-jaringan yang mengandung karbohidrat, protein dan lemak mengalami proses hidrolisis (degradasi yang hasilnya ditranslokasikan ke titik tumbuh embrio dan disintesakan kembali ke dalam jaringan baru) (Abidin, 1987).

Biji kesambi (Schleichera oleosa L) yang diperoleh dikecambahkan dengan cara direndam selama 24 jam dengan air dingin, untuk menghilangkan masa dormansi biji dan memperlunak permukaan kulit biji untuk proses penyerapan air. Setelah 24 jam biji kesambi ditanam pada media pasir. Media pasir mempunyai pori yang cukup besar dan tidak mudah menggumpal sehingga memudahkan tanaman untuk mengembangkan akarnya (Hardjowigeno, 2007).

Enzim lipase merupakan enzim yang dapat menghirolisis lemak (trigliserida) menjadi asam lemak dan juga gliserol. Aktivitas hidrolisis lipase dilakukan dengan metode titrasi. Proses hidrolisis ini dilakukan untuk mendapatkan aktivitas lipase tertinggi pada kecambah biji kesambi dengan umur kecambah yang bervariasi, proses hidrolisis dengan menggunakan substrat minyak kelapa dengan perbandingan 1:1 (5 ml substrat dan enzim). Pada tahap akhir hidrolisis akan terbentuk 2 lapisan yaitu lapisan atas asam lemak dan lapisan bawah gliserol (gambar 4.2) Enzim lipase ini dapat memecah ikatan ester pada lemak sehingga menjadi asam lemak dan gliserol (Poedjiadi dan Supriyanti, 2009).

Perkecambahan biji adalah tahapan penting dalam perkembangan tumbuhan dan menentukan produktivitas tumbuhan. Perubahan fisiologi dan biokimia diikuti

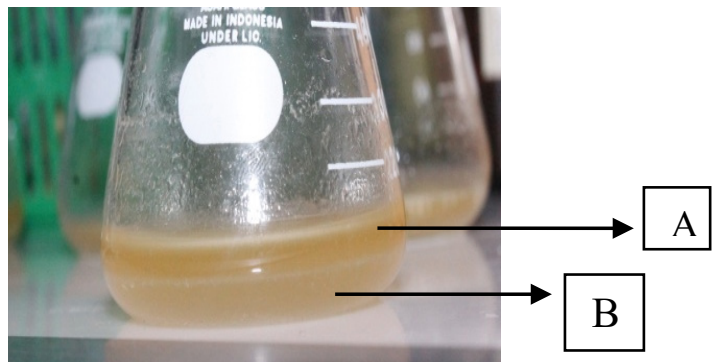

Gambar 2. Proses hidrolisis minyak kelapa oleh ekstrak kasar lipase dari kecambah biji kesambi menghasilkan 2 lapisan A: Lapisan atas : asam lemak ; b: Lapisan bawah : gliserol.

perubahan morfologi selama perkecambahan berkaitan erat dengan kecepatan perkecambahan dan pertumbuhan vegetatif yang berpengaruh pada hasil dan kualitasnya, Imbibisi biji memicu aktivasi berbagai proses metabolik seperti sintesis enzim hidrolisis yang dihasilkan pada hidrolisis cadangan makanan menjadi bentuk yang lebih sederhana untuk kebutuhan embrio. Aktivitas hidrolisis ekstrak kasar lipase dari kecambah biji kesambi dengan waktu perkecambahan yang berbeda tercantum pada Gambar 3.

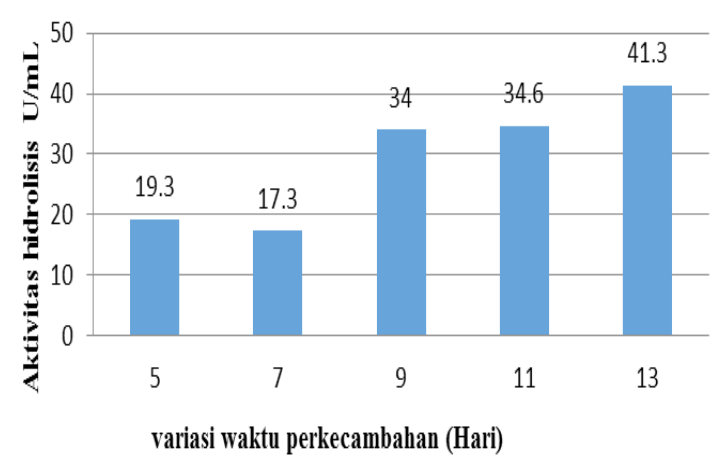

Gambar 3. Aktivitas hidrolisis ekstrak kasar lipase kecambah biji kesambi (U/ml) pada berbagai waktu perkecambahan

Aktivitas hidrolisis ekstrak kasar lipase kecambah biji kesambi meningkat seiring dengan meningkatnya waktu perkecambahan. Tingkatan lipid dan aktivitas lipase telah dipelajari pada berbagai jenis biji yang dikecambahkan, yang menunjukkan rekasi $\beta$-oksidasi pada perkecambahan biji jarak selama 4 hari. Sebagian besar enzim hidrolisis berperan dalam metabolisme 
lipid selama perkecambahan, enzim lipase mengkatalisis hidrolisis ikatan ester karboksilat dan melepaskan asam lemak dan alkohol organik, dan reaksi timbal balik (esterifikasi) atau beberapa reaksi transesterifikasi. Kemampuan lipase untuk mengkatalisis reaksi ini dengan efisisensi, stabilitas dan berbagai manfaat yang besar menyebabkan enzim ini menarik untuk kepentingan komersial.

Demikian juga dengan perkecambahan biji rami, aktivitas lipase yang paling tinggi pada hari yang terakhir karena pada tahap ini kecambah membutuhkanmakromolekul untuk pembentukan organ-organ tumbuhan secara normal (Samour, 2005). Selama perkecambahan akan terjadi peningkatan jumlah enzim lipase yang digunakan untuk mendegradasi lemak menjadi komponen metabolik yang diperlukan untuk pertumbuhan biji.

Penelitian Sana et al. (2004), mengalami fenomena yang sama yaitu pada biji sawit, pada awal perkecambahan aktivitas spesifik cukup tinggi karena terjadi pembentukan lipase untuk mengurai cadangan makanan dalam kecambah, setelah mengalami pertunasan maka terjadi penurunan pada hari ke 7 akibat berkurangnya cadangan makanan, hal ini menyebabkan selama masa perkecambahan akan terjadi penurunan aktivitas spesifik enzim akibat berkurangnya cadangan makanan. Aktivitas spesifik ekstrak kasar lipase kecambah biji kesambi ditentukan dengan melakukan pengukuran kandungan protein pada sampel ekstrak kasar lipase kecambah biji kesambi untuk kemudian dihitung dengan persamaan aktivitas spesifik (Gambar 4).

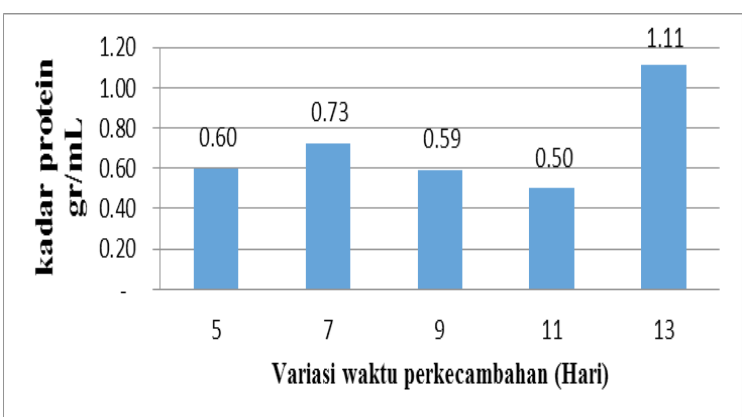

Gambar 4. Grafik hubungan antara variasi waktu perkecambahan dan kadar protein ekstrak kasar lipase kecambah biji kesambi (gr/ml)
Kandungan protein pada ekstrak kasar lipase kecambah biji kesambi cenderung fluktuatif namun mengalami peningkatan pada hari ke 13. Perbandingan analisis 2 dimensi antara biji Podophyllum hexandrum yang tidak berkecambah dan biji yang berkecambah mengungkapkan ekspresi 113 protein, dimana analisis fingerprint massa peptida dari 97 spot protein mengungkapkan ekspresi 27 protein, namun terjadi kehilangan 40 protein saat perkecambahan. 59 protein diidentifikasi dalam pencarian homologi termasuk didalamnya 20 protein dalam metabolisme karbohidrat dan asam amino, 17 protein sinyal ABA/GA, dan 15 protein dalam kondisi cekaman dan 7 protein yang belum diketahui fungsinya (Dogra et al., 2013), dengan demikian penurunan kandungan protein pada ekstrak kasar lipase kecambah biji kesambi selama terjadinya proses perkecambahan, disebabkan protein yang besar dipecah menjadi asam amino. Hidayat (1995), mengatakan bahwa perkecambahan dapat terjadi apabila substrat (protein) berperan sebagai penyedia energi yang akan digunakan dalam proses morfologi (pemunculan organ-organ tanaman seperti akar, daun,dan batang). Protein (cadangan nitrogen pada biji), merupakan polimer asam amino yang dihubungkan dengan ikatan peptida.

Aktivitas spesifik ekstrak kasar lipase kecambah biji kesambi pada waktu perkecambahan yang berbeda tercantum pada Gambar 5.

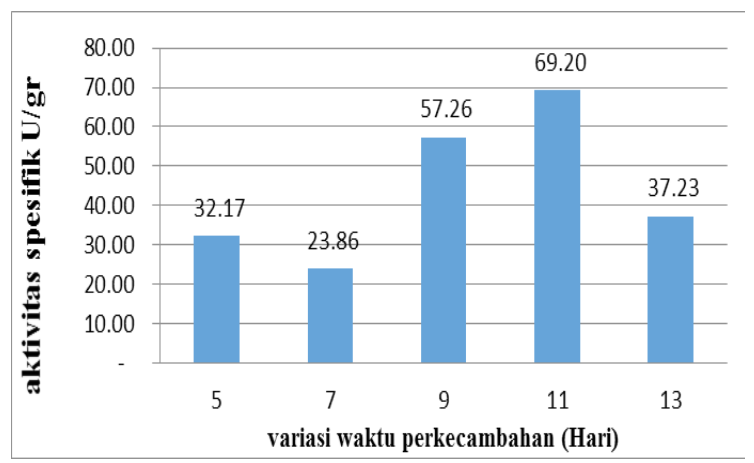

Gambar 5. Grafik hubungan antara variasi waktu perkecambahan terhadap aktivitas spesifik ekstrak kasar lipase kecambah biji kesambi (U/gr) 
Pada waktu perkecambahan selama 11 hari merupakan aktivitas spesifik tertinggi dengan 69,20 U/gr sedangkan aktivitas terendah pada hari ke 7 dengan aktivitas 23,86 $\mathrm{U} / \mathrm{mg}$, aktivitas spesifik ekstrak kasar lipase biji kesambi pada hari ke 11 menunjukan bahwa meskipun kadar proteinnya rendah tetapi aktivitas spesifiknya tinggi hal ini mengindikasikan bahwa protein pada ekstrak kasar lipase kecambah biji kesambi di hari ke 11 adalah protein enzim khususnya enzim lipase. Pada hari ke 13 kecambah biji kesambi memiliki kadar protein yang sangat tinggi namun memiliki aktivitas spesifik yang rendah hal ini menunjukan bahwa tidak semua protein yang di produksi adalah enzim lipase.

Hal ini menegaskan bahwa kadar protein tertinggi tidak mutlak memiliki aktivitas lipase yang tinggi, makin tinggi aktivitas spesifik menunjukan kualitas yang baik suatu enzim yang lebih tinggi (Yuneta 2010). Sya'bani et al. (2017), yang menguji aktivitas enzim spesifik pada kecambah biji alpukat menyatakan bahwa semakin tinggi akivitas spesifik suatu enzim maka semakin tinggi juga tingkat kemurnian enzim tersebut. Aktivitas spesifik hari ke 11 sangat di rekomendasikan untuk digunakan dalam penelitian karena meskipun memiliki aktivitas hidrolisis yang tidak setinggi hari ke 13 dan kadar protein yang rendah tapi memiliki aktivitas spesifik yang tinggi.

\section{Kesimpulan}

Aktivitas hidrolisis ekstrak kasar lipase kecambah biji kesambi tertinggi adalah hari ke 13 sebesar 41,33 U/ml, kadar protein tertinggi pada hari ke 13 sebesar gr/ml, aktivitas spesifik tertinggi pada hari ke 11 sebesar 69,20 U/gr.

\section{Daftar Pustaka}

Abidin, Z. (1987). Dasar Pengetahuan Ilmu Tanaman. Bandung : Angkasa.

Abigor, R.D., Uadia, P.O., Foglia, T.A., Hass, M.J., Scott, K., \& Savary, B.J. (2002). Partial and properties of lipase from germaning seeds of Jatropha curcas L. Journal of the American Oil Chemists Society, 79, 1123-1126.
Ali, S.A \& Elozoiri, A.A.(2017). Metabolic Processes During Seed Germination. Journal Intech, 141-166

Debeaujon, I., Lepeniec, L., Pourcel, L., \& Routaboul, J-M. (2007). Seed coat development and dormancy. Dalam: Bradford, K.J. dan Nonogasaki, H. (ed). Seed Development, Dormancy and Germination, pp. 25-49. Blackwell Publishing. Oxford.

Djarkasi G. S. S., Raharjo, S., \& N, Zuheid. (2017). Isolasi Dan Aktivitas Spesifik Enzim Lipase Indigenous Biji Kenari. Jurnal Teknologi Pertanian. Vol 8(1).

Hardjowigeno, S. (2007). Ilmu Tanah. Jakarta: Akademika Pressindo, pp.296

Hendra, W., Wibowo, S., \& Wibisono, S. (2018). Biodiesel Dari Beberapa Jenis Tanaman. IPB Press. Bogor.

Hidayat, C., Kuntoro, M.D., Hastuti, P., Sumangat, D., \& Hidayat, T. (2008). Optimasi Sintesis Metil Oleat Menggunakan Biokatalis Lipase Dari Kecambah Biji Jatropha curcas L. Jurusan Teknologi Pangan dan Hasil Pertanian UGM. Yogyakarta.

Hidayat, E.B. (1995). Anatomi Tumbuhan Berbiji, Institut Teknologi Bandung, Bandung.

Lowry, O. H., N. J., Rosebrough, A. L., Farr., \& R. J. Randall. (1951). Protein measurement with the folin phenol reagent. The Journal of Biological Chemistry, 193-265.

Pahoja, V.M., M.U. Dahot., \& M. A. Sethar, (2001). Characteristic Properties of Lipase from Crude Extract of Caesalpinia bonducella L. Seeds. Journal of Biological Science, 1(8), 775-778.

Pelezar, M. J \& Chan, E. C. S. (2005). DasarDasar Mikrobiologi Jilid I . Penerjemah Hardiantomo, R. S., Imas, T., Tjitrosomo, S. S., dan Angka, S. L. UI-Press, Jakarta.

Pera, L. M., C. M. Romero, M. D. Baigori., \& G. R. Castro. (2006). Catalytic Properties Of Lipase Extracts From Aspergillus Niger. Food Technology and Biotechnology, 44(2), 247-252.

Permana, I. D G., Indrati, R., Hastuti, P., \& Suparmo. (2013). Aktivitas Lipase Indegenous Selama Perkecambahan 
Biji Kakao(Theobroma Cacao L). Jurnal Agritech, 33(2).

Poedjiadi, A \& Supriyanti, F.M.T. (2009). Dasar-Dasar Biokimia. Penerbit Universitas Indonesia. Jakarta.

Polizelli, P.P., Tiera, M.J., \& BonillaRodriguez, G.O. (2008). Effect of surfactants and polyethylene glycol on the activity and stability of a lipase from oilseeds of Pachira aquatica. Journal of the American Oil Chemists Society, 85, 749-753.

Sagiroglu, A \& N. Arabaci. (2005). Sunflower Seed Lipase: Extraction, Purification, and Characterization. Preparative Biochemistry and Biotechnology, 35 (1), 37-51.

Saktiwansyah, E. (2001). Karakterisasi Enzim Lipase Intraseluler Dengan Aktivitas Esterifikasi Dari Kapang Rhizopus Oryzae TR 32 [Tesis]. Program Pascasarjana, IPB, Bogor.

Sammour, R.H. (2005). Purification and partial characterization of an acid lipase in germinating lipidbody linseedlings. Turkish Journal of Botany, 29(3), 177-184.

Sana, H.I., Haque, E.M., \& Shaha, R.K. (2004). Identification, purification and characterization of lipase from germination oil seed (Brassica napus L.). Pakistan Journal of Biological Sciences, 7(2), 246-252.

Sele, Y \& Ledo, M. (2013). Identifikasi Fungi Lipolitik Yang Diisolasi Dari Biji Kesambi. Jurnal Biotropikal Sains, 2(3),82-88, Universitas Nusa Cendana.

Seran, Y. K. (2011). Isolasi Karakteristik Dan Identifikasi Asam Lemak Utama Biji Kesambi (Schleichera Oleosa L) [Skripsi], Universitas Negeri Malang, Malang.

Siregar, N. A. (2011). Penentuan pH dan Suhu Optimum untuk Aktivitas Ekstrak Kasar Enzim Lipase dari Kecambah Biji Jarak Kepyar (Ricinus communis L) Terhadap Hidrolisis Minyak Wijen [Skripsi]. FMIPA USU : Medan.

Su'i, M., Harjono., Yuanita., \& Aulani'am. (2011). Aktivitas Enzim Lipase Dari Buah Kelapa Selama Perkecambahan. Berkala Penelelitian Hayati, 16,155-159.
Suhendra, L., Tranggono., \& Hidayat, C. (2007). Aktivitas Hidrolisis dan Esterifikasi Lipase Ekstrak Kecambah Biji Wijen (Sesamun indicum). Jurusan Teknologi Pangan dan Hasil Pertanian UGM. Yogyakarta

Suita, E. (2012). Seri Teknologi Perbenihan Tanaman Hutan Kesambi (Schleichera Oleosa)Balai Penelitian Teknologi Perbenihan Tanaman Hutan. Bogor.

Sutopo, 1. (2002). Teknologi Benih . PT Raya Persada. Jakarta.

Sya'bani, N., Astuti, W., \& Pratiwi, D. R. (2017). Isolasi Dan Karakterisasi Lipase Dari Kecambah Alpukat (Persea Americana Mill). Jurnal Atomik, 02(2), 209-212.

Winarno, F.G. (1989). Enzim Pangan dan Gizi.PT. Gramedia Pustaka Utama. Jakarta. pp. 155

Winarno. F.G. (1995). Enzim Pangan. Jakarta: Gramedia Pustaka Utama.

Yuneta, R \& Putra, S.R. (2010). Pengaruh Suhu pada Lipase dari Bakteri Bacillus subtilis. Prosiding Kimia FMIPA. Surabaya: Institut Teknologi Sepuluh Nopember 